\title{
Identification of temperature effect on post-critical geomechanical properties of loaded sandstones
}

\author{
Anna Sygała $^{1} \cdot$ Mirosława Bukowska $^{1}$ \\ Received: 23 September 2018 / Accepted: 1 April 2019 / Published online: 8 May 2019 \\ (C) The Author(s) 2019
}

\begin{abstract}
Geomechanical changes in the post-critical residual strength and strain of Carboniferous sandstones from the Upper Silesian Coal Basin, Poland, were measured from uniaxial compression tests. Rock samples were subjected to high temperatures of up to $1200{ }^{\circ} \mathrm{C}$. Sandstone samples of different grain sizes were collected from all currently exploited lithostratigraphic members of coal-bearing Carboniferous sandstones across the Upper Silesian Coal Basin, including the Upper Silesian Sandstone Series (Ruda Beds and Saddle Beds). The samples were heated to temperatures between 100 and $1200^{\circ} \mathrm{C}$, cooled to room temperature, and subsequently tested by uniaxial compression in a servo-controlled testing machine MTS- 810 NEW. The analysis of results followed a grain size and room temperature uniaxial compressive strength classification scheme. Normalized indices of the thermal influence on residual strength and residual strain were calculated. The new measure, namely the indices of thermal influence, can be used to predict the stability of rock masses subjected to high temperatures. The conducted research in terms of evaluation of post-critical parameters subjected to high temperatures as well as the method of analyzing the results are novel and are of primary importance from the engineering (mining and geoengineering) applications point of view.
\end{abstract}

Keywords Rock $\cdot$ Residual strength $\cdot$ Residual strain $\cdot$ Temperature $\cdot$ Normalized index

\section{Introduction}

Temperature is one factor that can alter the physical properties in rock. As temperature increases, thermal expansion of rockforming minerals weakens the rock mass and may cause its destruction (Dimitriyev et al. 1969; Heuze 1983; Somerton 1992; Den'gina et al. 1994; Hajpál and Török 2004; Sygała et al. 2013; Cieślik 2015). Changes in physical rock properties under high temperatures may have a practical impact on in situ mining deposits, as well as creating issues for mine safety. Other factors impacting geomechanical property changes include the flow of water into the underground mine and the rock properties of the rubble within post-mining goaves and closed shafts (Bukowski and Augustyniak 2013; Bukowski

Editorial handling: Pinnaduwa Kulatilake

Anna Sygała

asygala@gig.eu

1 Department of Rockburst and Rock Mechanics, Central Mining Institute, Katowice, Poland and Niedbalska 2013). For example, water conditions may affect a georeactor during the underground coal gasification process. These factors, as well as others, have contributed to the development of modern mining technologies (Drzewiecki and Kabiesz 2008) and must be taken into consideration while assessing innovative methods (Kabiesz et al. 2008). These factors are of particular importance for deep mining operations and special mining technologies, such as crude oil and natural gas extraction, coal deposit gasification, geothermal energy production, or nuclear waste storage (Hettema et al. 1992, Zhang et al. 2001, Zuo et al. 2010, Paul and Younger 2011, Bhutto et al. 2013, Lu et al. 2016), as well as assessing safety hazards (Bukowski 2015). Understanding the mechanism of rock property changes with temperature is a significant challenge facing engineers in geomechanics and geoengineering.

Many institutions around the world have researched the physical, mechanical, and thermal properties of rocks under high temperatures (Hettema et al. 1993; Yavuz et al. 2010; Brotóns et al. 2013; Lu et al. 2016; Tian et al. 2016). Results from this past work clearly show that rock quality changes with temperature (e.g., Tian et al. 2012, 2014; Shi and Jinyu 2015). However, datasets are wide-ranging, and it is difficult to characterize uniformly the behavior of rocks under high 
temperatures. The thermal influence on the behavior of rocks is closely dependent on the heating conditions, rock type, mineralogy, distribution of microfissures and primary cracks, density, porosity, and many other factors (Chaki et al. 2008; Keshavarz et al. 2010; Sygała et al. 2013).

Among the geomechanical properties of rocks, strength and strain properties in the pre-critical phase of the stressstrain relationship are the most researched. In those studies, uniaxial compression tests were conducted on rock samples. It was observed that under increasing temperatures, the strength of rocks can either increase or decrease until reaching a certain critical temperature, at which point the strength rapidly decreases as the temperature continues to rise. Elastic properties of rocks strongly correlate with their yield strength. Young's modulus can increase or decrease with temperature, as well as the uniaxial compressive strength. At greater temperatures, the value of Young's modulus decreases from the air-dry state. Research also indicates that there is a general increase in critical strain with an increase in temperature. Reaching a maximal value of critical strain may be preceded by huge fluctuations in strain, resulting from thermal transformations and reactions occurring in the rock. At temperatures between 500 and $600{ }^{\circ} \mathrm{C}$, plastic behavior increases as a result of softening of the rock structure (Rao et al. 2007; Zhang et al. 2009; Mao et al. 2009; Zhi-jun et al. 2009; Keshavarz et al. 2010; Ranjith et al. 2012; Zhang et al. 2013).

Changes in rock properties in the pre-critical phase of the stress-strain relationship of uniaxially loaded rock under high temperatures have been studied in numerous publications (Ferro and Marrini 2001; Su et al. 2008; Małkowski et al. 2012; Chen et al. 2012; Wu et al. 2013; Gautam et al. 2016). However, data on changes in the post-critical geomechanical properties, which are obtained from the post-critical stressstrain relationship, are lacking. To date, only few similar tests have been performed (Siegesmund et al. 2008; Wang et al. 2015), although research examining post-critical geomechanical properties and rock stability is crucial for the mining industry and geoengineering in general. Changes in post-failure properties may also predict whether geodynamic phenomena, such as rockbursts, will occur in mines. This knowledge is indispensable for assessing susceptibility of the rock mass to rockbursts and rockburst hazards (Bukowska 2013). Modern deep mining operations, as well as unconventional mining methods, where high temperatures are a constant and inseparable element of the process necessitates research on these issues.

Abovementioned aspects have become motivations for performing the research on the temperature influence on postcritical properties of loaded rocks. Therefore, this paper presents results concerning the thermal influence on residual strength and residual strain of Carboniferous sandstones, which accompany coal seams currently mined in the Upper Silesian Coal Basin (USCB), Poland. As a measure of thermal effect on geomechanical properties of rocks, a normalized coefficient, referred to as the index of thermal influence, is introduced.

\section{Experimental methods}

Cylindrical rock samples, $30 \mathrm{~mm}$ in diameter and $60 \mathrm{~mm}$ in height, were collected from Carboniferous sandstones of different grain sizes. The samples were selected from each of the currently mined stratigraphic groups of coal-bearing Carboniferous from mines located around the USCB. Twenty-four series of sandstone samples were tested: 4 series of coarse-grained sandstones, 9 series of medium-grained sandstones, and 11 series of fine-grained sandstones. In total, 366 sandstone samples were tested: between one and five samples for each temperature series were analyzed and final values of geomechanical properties were evaluated as the mean values.

Different series of sandstones characterized by various grain composition were investigated since grain size strongly influences mechanical parameters, especially the post-critical ones. For example fine-grained sandstones, in comparison to coarsegrained ones, exhibit usually lower values of post-critical properties in the area of Upper Silesian Coal Basin (USCB) in Poland. Sandstones of various grain sizes, in some cases, constitute direct coal seam roofs in USCB. Therefore, distinguishing of geomechanical properties in accordance with grain size of sandstones is of primary importance for exploitation works, e.g., in case of underground coal gasification.

Before testing, the samples were heated to a temperature between 100 and $1000{ }^{\circ} \mathrm{C}$ in increments of $100{ }^{\circ} \mathrm{C}$ or $1200{ }^{\circ} \mathrm{C}$. Samples for the temperature range of 100 to $1000{ }^{\circ} \mathrm{C}$ were heated for $8 \mathrm{~h}$ in a resistance furnace. Heating to $1200{ }^{\circ} \mathrm{C}$ (for $24 \mathrm{~h}$ ) was conducted in a hightemperature Nabertherm HT16/16 furnace with P310 controller and a gas supply system. To obtain comparable rock heating conditions, the heating rate was set at $16^{\circ} \mathrm{C} / \mathrm{min}$ in both furnaces. In each of the series, selected samples were tested in an air-dry state at room temperature without prior heating. After heating, the samples were placed in a desiccator until they cooled to room temperature. The samples heated to $1200{ }^{\circ} \mathrm{C}$ were cooled in the furnace to approximately $50{ }^{\circ} \mathrm{C}$ and subsequently cooled in a desiccator to avoid a rapid change in temperature. Two exemplary series of sandstone samples after heating to $1000{ }^{\circ} \mathrm{C}$ are shown in Fig. 1 . First from the left is the specimen in air-dried state. Next samples (to the right) are representing the case of temperature heating from 100 to $1000{ }^{\circ} \mathrm{C}$ every $100{ }^{\circ} \mathrm{C}$. This means that second from the left is the sample after $100{ }^{\circ} \mathrm{C}$, third from the left is the sample after $200^{\circ} \mathrm{C}$, etc. In Fig. 2, chosen rock samples after $1200{ }^{\circ} \mathrm{C}$ heating are presented. A significant and diverse changes in the color of samples are observed; however, the shape of samples remains unchanged. 
Fig. 1 Sandstone samples after thermal treatment at different temperatures
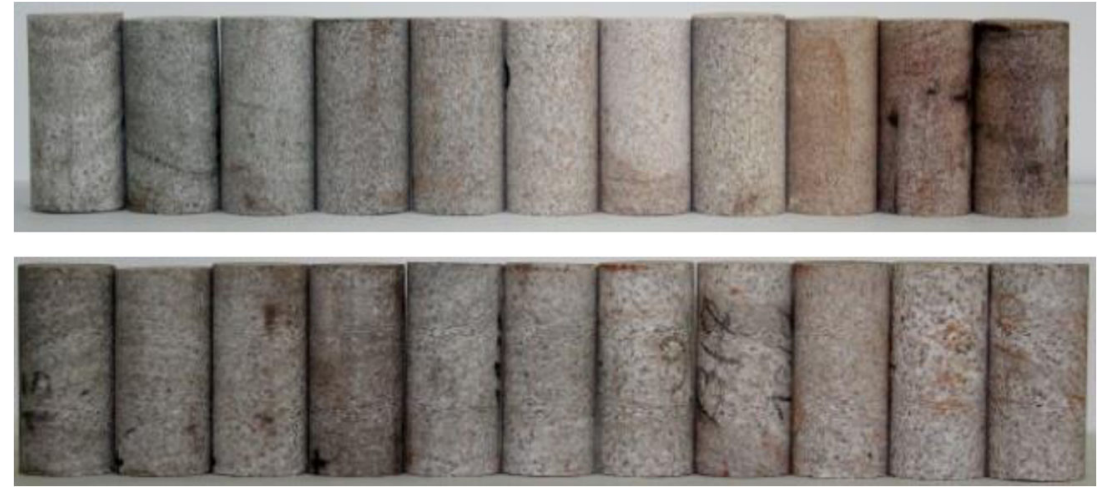

Values of post-critical properties were determined from a full strain range uniaxial compression test in the servo-controlled testing system MTS-810 NEW. The tests followed current procedures based on Polish standards and the International Society for Rock Mechanics guidelines (Ulusay and Hudson 2007). Among other post-critical properties, values of residual strength $\left(\sigma_{r}\right)$ and residual strain $\left(\varepsilon_{r}\right)$ were determined. Residual strength was determined from the post-critical phase of the stress-strain relationship of a rock sample loaded in the servo-controlled testing machine; the residual strain was defined as the total strain at the end of the uniaxial compression test (Fig. 3).

\section{Thermal influence on post-critical parameters}

As a measure of thermal influence on post-critical parameters of rocks, the following indices of thermal influence, $I_{p}(T)$, are introduced, i.e.:

$I_{p}(T)=\frac{p(T)}{p(R T)}$

where $p(T)$ and $p(R T)$ are the values of considered post-critical property (residual strength or residual strain) evaluated after temperature $T$ treatment or at room temperature, respectively. Obviously, as mentioned above, both $p(T)$ and $p(R T)$ are representing mean values evaluated for the series of samples investigated at each temperature.

Indices of the thermal influence on residual strength and residual strain, with respect to Eq. (1), were determined for sandstones from the various lithostratigraphic members of the Upper Carboniferous sandstone in the USCB. From these results, predictive thermal influence indices are discussed. The residual strengths were normalized by the corresponding value of uniaxial compressive strength of the corresponding sample tested in an air-dry room temperature state (Bukowska 2012). The samples were classified into very low (< $20.0 \mathrm{MPa}$ ), low (20.0-40.0 MPa), medium (40.1$60.0 \mathrm{MPa}$ ), and high (>60.0 MPa) uniaxial compressive strength groups. This classification was established for rocks of Carboniferous formation based on many years of experience of the author (Bukowska 2012).

Sandstones are very common sedimentary rocks in Poland. These rocks are found in the Carpathian Flysch Belt, near the Świętokrzyskie Mountains and Lower Silesia region. In the USCB, sandstones are interbedded with coal seams (Chodynicka et al. 1993).

In this area, Carboniferous sandstones have various grain sizes, ranging from coarse-grained to fine-grained. The thickness of sandstone beds varies with lithostratigraphic member. In the USCB, sandstones are prevalent in the Cracow Sandstone Series (up to 90\% sandstone) and the Upper Silesian Sandstone Series (approximately 53\% sandstone). In other lithostratigraphic series, the proportions of sandstones are still significant, for example, in the Paralic Series (approximately 47\% sandstone) and Mudstone Series (approximately $27 \%$ sandstone).

The post-critical geomechanical testing results are discussed relative to two metrics of each sample type: grain size and the air-dry state uniaxial compressive strength.
Fig. 2 Sandstone samples after treatment at $1200{ }^{\circ} \mathrm{C}$

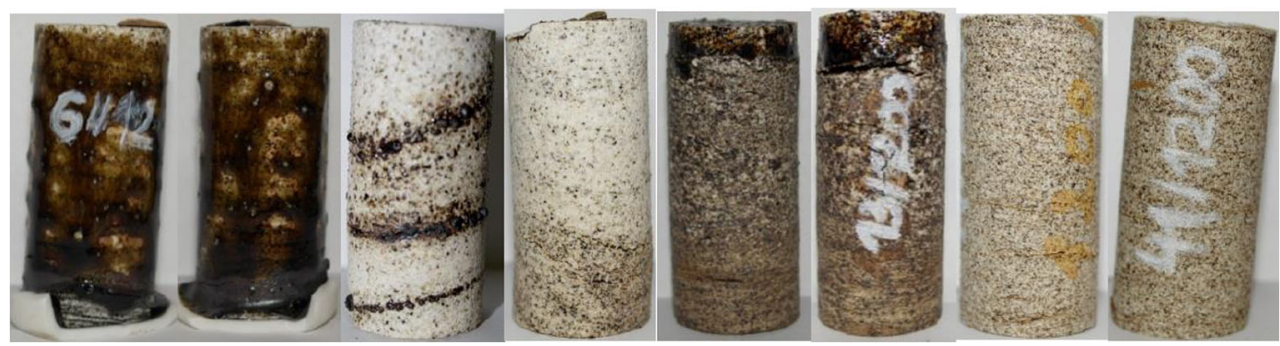




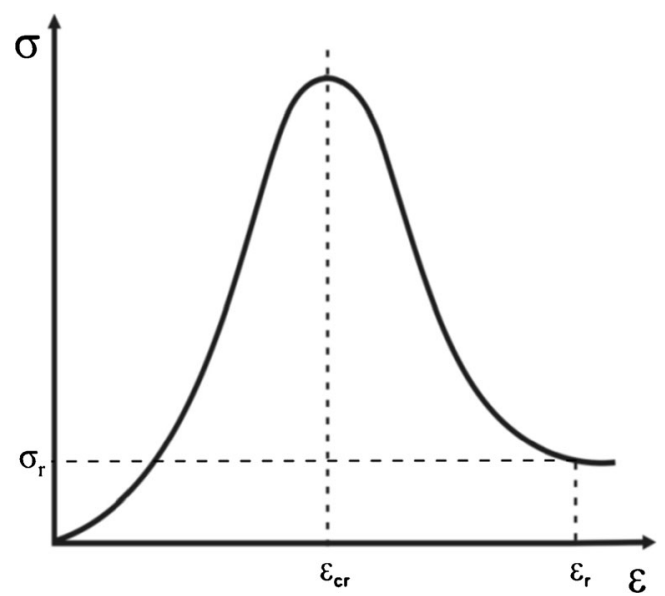

Fig. 3 Stress-strain curve: $\sigma_{r}$ is residual strength, $\varepsilon_{c r}$ is critical strain, and $\varepsilon_{r}$ is residual strain (total)

\section{Results and discussion}

\section{Thermal influence on residual strength}

Ranges of the room temperature uniaxial compressive strength and residual strength of the sandstone samples are presented in Table 1.

Table 2 shows the indices of thermal influence on residual strength, determined from normalizing the residual strength of the heated sandstones with that of the room temperature experiments and categorized by grain size and uniaxial compressive strength classification (Eq. 1). Note that each sample type, characterized by grain size and the room temperature strength assessment, is consecutively numbered from 1 to 10 ; these numbers are provided in the first column of Table 2 . These numbers are consistently used throughout the paper.

All the results, namely the values of indices of thermal influence on residual strength (Table 2), are also graphically presented in Fig. 4. Here, the results are provided on three separate plots representing three categories of room temperature strength assessment. In particular, Fig. 4a shows the index values of thermal influence for the case of very low, low and medium, or very low and low uniaxial compressive strength values (sample types 1,2 , and 3 ). Figure $4 b$, c corresponds to the case of medium (sample types 4, 5, 8, and 9) and high (sample types 6, 7, and 10) uniaxial compressive strength assessment, respectively.

Observing the results, we can notice that coarse-grained sandstones with very low to medium uniaxial compressive strength exhibited either an increase or a decrease in residual strength at lower temperatures (up to $200^{\circ} \mathrm{C}$ ) compared to the residual strength for the same rock type at room temperature. The range in increased residual strength for rocks with very low to medium uniaxial compressive strength was between 40 and $225 \%$, and the range in decreased residual strength was estimated to be between 44 and $63 \%$. The samples with very low to medium uniaxial compressive strength that were heated at higher temperatures (over $400^{\circ} \mathrm{C}$ ) systematically decreased in post-critical residual strength. In the samples of very low to medium uniaxial compressive strength that were heated to $1000{ }^{\circ} \mathrm{C}$, a reduction in residual strength between 66 and $73 \%$ was observed.

Among medium-grained sandstones, residual strength varies with the sample preparation. Medium-grained sandstones with medium uniaxial compressive strengths in an air-dry state have greater residual strength than heated samples. Heated medium-grained sandstones of very low and low strength either decrease or increase in residual strength. Medium-grained sandstones heated to a temperature of $100{ }^{\circ} \mathrm{C}$ can exhibit decreased residual strengths from 10 to $71 \%$ compared with the residual strength obtained from an equivalent room temperature experiment. Certain mediumgrained sandstones of high uniaxial compressive strength (for example, the Laziska Beds) show only small fluctuations of values of residual strength around the control value. Medium-grained sandstones collected from the Saddle Beds exhibited an interesting change in residual strength with temperature, unlike other samples (Table 2). Examples of stressstrain paths for considered sandstones at selected temperatures are presented in Fig. 5. For other samples from this stratigraphic group, residual strength significantly increases with temperature, reaching $300 \%$. Medium-grained sandstones from different classes of uniaxial compressive strength
Table 1 Ranges of residual strength of Carboniferous sandstones in an air-dry state at room temperature

\begin{tabular}{lll}
\hline Sandstone grain size & Uniaxial compressive strength assessment & Residual strength MPa \\
\hline Coarse-grained & Very low (<20.0 MPa) & $0.38-2.19$ \\
& Low (20.0-40.0 MPa) and medium $(40.1-60.0 \mathrm{MPa})$ & $3.45-4.38$ \\
Medium-grained & Very low $(<20.0 \mathrm{MPa})$ and low $(20.0-40.0 \mathrm{MPa})$ & $1.21-2.66$ \\
& Medium $(40.1-60.0 \mathrm{MPa})$ & $1.15-10.18$ \\
& High $(>60.0 \mathrm{MPa})$ & $3.13-4.38$ \\
Fine-grained & Medium $(40.1-60.0 \mathrm{MPa})$ & $1.96-5.09$ \\
& High $(>60.0 \mathrm{MPa})$ & $1.52-5.44$ \\
\hline
\end{tabular}


Table 2 Indices of thermal influence on residual strength of Carboniferous sandstones, Eq. (1)

\begin{tabular}{|c|c|c|c|c|c|c|c|c|c|c|c|c|c|}
\hline \multirow[t]{2}{*}{ No. } & \multirow[t]{2}{*}{ Sandstone grain size } & \multirow[t]{2}{*}{ Strength assessment } & \multicolumn{11}{|c|}{ Index of thermal influence on residual strength, Eq. (1) } \\
\hline & & & 100 & 200 & 300 & 400 & 500 & 600 & 700 & 800 & 900 & 1000 & 1200 \\
\hline 1 & Coarse-grained & V. low & 3.25 & 0.37 & 2.03 & 0.94 & 0.45 & 0.89 & 0.23 & 0.29 & 0.46 & 0.34 & - \\
\hline 2 & Coarse-grained & Low and medium & 0.56 & 1.40 & 1.26 & 1.45 & 0.89 & 0.53 & 0.46 & 0.38 & 0.51 & 0.27 & - \\
\hline 3 & Medium-grained & V. low and low & 0.90 & 0.75 & 0.88 & 0.81 & 0.60 & 0.72 & 0.88 & 0.59 & 0.39 & 0.38 & - \\
\hline 4 & Medium-grained & Medium & 0.29 & 0.32 & 0.19 & 0.36 & 0.65 & 0.47 & 0.38 & 0.41 & 0.09 & 0.24 & 0.04 \\
\hline 5 & Medium-grained & Medium* & 1.33 & 1.08 & 4.13 & 2.56 & 2.32 & 2.80 & 2.66 & 3.24 & 2.43 & 0.61 & - \\
\hline 6 & Medium-grained & High & 1.11 & 0.78 & 1.20 & 0.57 & 0.97 & 1.45 & 0.73 & 0.77 & 1.31 & 0.79 & 0.29 \\
\hline 7 & Medium-grained & High** $^{*}$ & 0.77 & 0.75 & 0.56 & 0.68 & 0.84 & 0.41 & 0.12 & 0.12 & 0.12 & 0.13 & - \\
\hline 8 & Fine-grained & Medium (1) & 0.80 & 0.57 & 0.54 & 0.48 & 0.87 & 0.84 & 0.97 & 0.30 & 0.39 & 0.34 & 0.42 \\
\hline 9 & Fine-grained & Medium (2) & 0.87 & 3.41 & 1.62 & 2.09 & 0.65 & 0.89 & 0.98 & 1.29 & 0.66 & 0.51 & 0.61 \\
\hline 10 & Fine-grained & High & 1.45 & 0.55 & 0.96 & 0.97 & 1.23 & 1.65 & 0.82 & 1.08 & 0.73 & 0.54 & 0.39 \\
\hline
\end{tabular}

* Saddle Beds

** Laziska Beds

decreased in residual strength by approximately $20-90 \%$ at the temperature of $1000{ }^{\circ} \mathrm{C}$ and by approximately $70-90 \%$ at the temperature of $1200^{\circ} \mathrm{C}$.
Fine-grained sandstones with a medium uniaxial compressive strength heated to $100^{\circ} \mathrm{C}$ exhibit a decrease in residual strength by $13-20 \%$. Similar rock types heated to higher
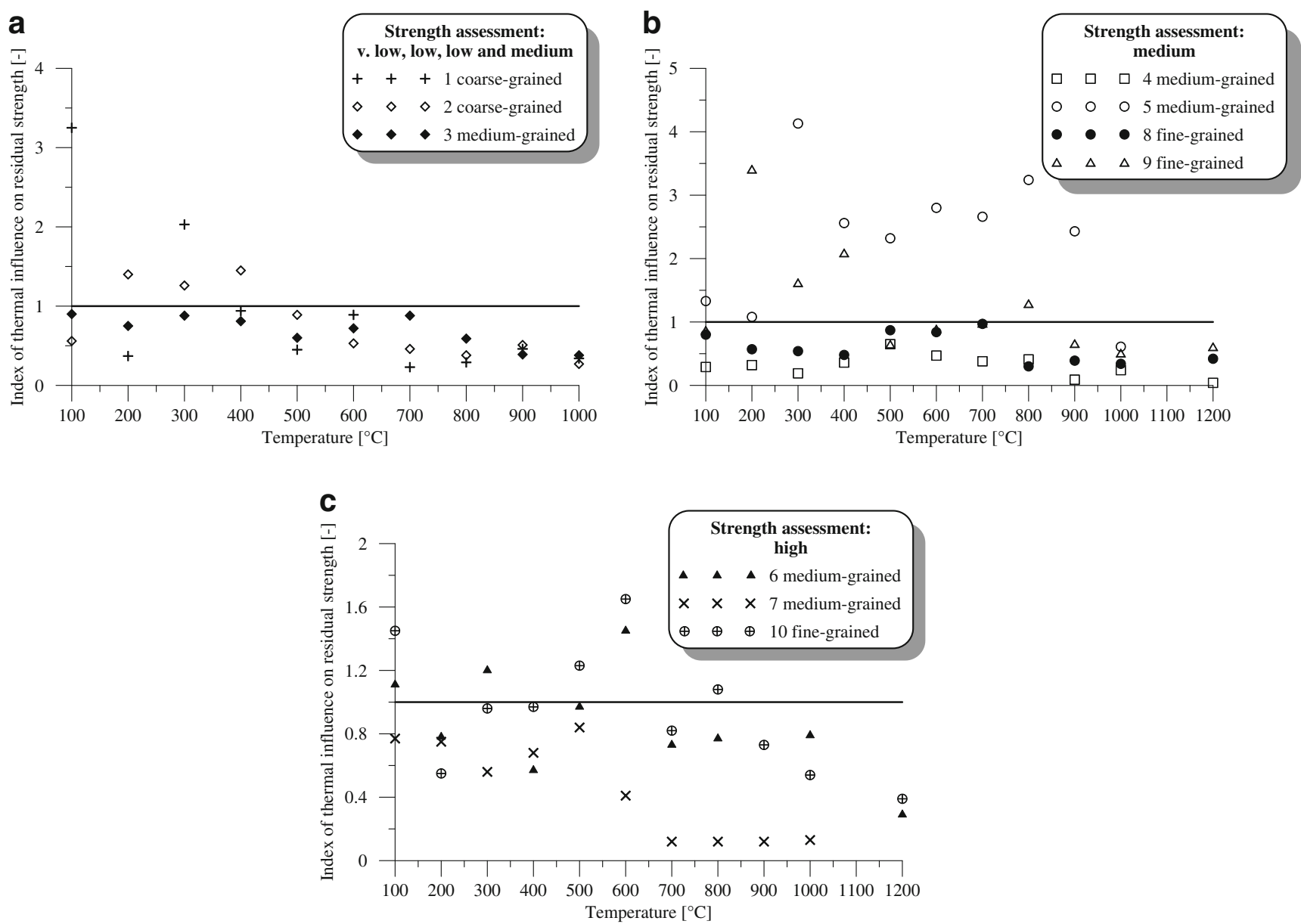

Fig. 4 Indices of thermal influence on residual strength versus temperature categorized by strength assessment. a V. low, low and medium, v. low and low. b Medium. c High 


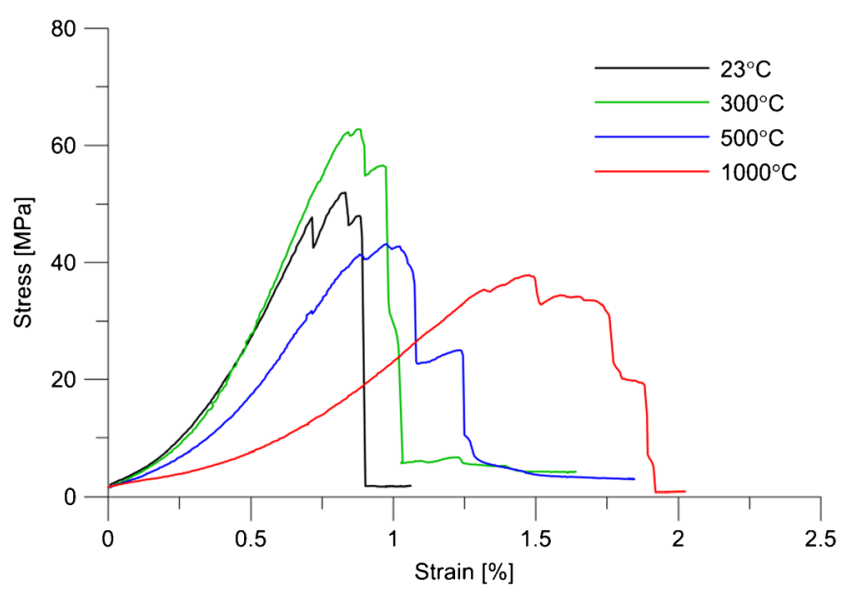

Fig. 5 Stress-strain paths for medium-grained Saddle Beds sandstone

temperatures can show significant differences, that is, either (1) decreased residual strengths for all heated samples or (2) significantly increased residual strength for samples heated to 200, 300, 400, and $800{ }^{\circ} \mathrm{C}$ (Fig. 6). Heated samples of finegrained sandstones decreased in residual strength by approximately $30-60 \%$.

From the test results for these Carboniferous sandstone samples, the thermal influence on residual strength was predicted for the uniaxial compressive strength classes discussed above.

The tests indicated that for certain heated samples of sandstones of very low to low uniaxial compressive strength, the value of residual strength decreased 6-55\% with heating. Certain samples decreased in residual strength at $100{ }^{\circ} \mathrm{C}$, but others started to decrease from 400 to $500{ }^{\circ} \mathrm{C}$. In samples heated to $1000{ }^{\circ} \mathrm{C}$, the reduction in residual strength can be over $70 \%$.

For medium-grained and fine-grained sandstones of medium uniaxial compressive strength (40.1-60.0 MPa) (Table 2), the residual strengths for heated samples were always less than the room temperature samples. The residual strength of sandstones heated to $100{ }^{\circ} \mathrm{C}$ can decrease by approximately 20 $70 \%$ in comparison with initial residual strengths. Residual

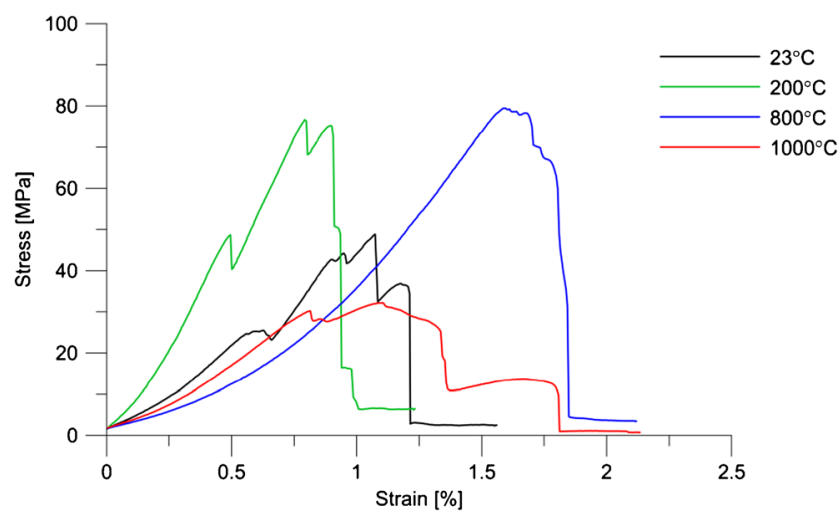

Fig. 6 Stress-strain paths for fine-grained sandstone of medium uniaxial compressive strength strength for the samples heated to $1200{ }^{\circ} \mathrm{C}$ can decrease from $60 \%$ to over $90 \%$.

For the group of fine- and medium-grained sandstones of medium uniaxial compressive strength (Table 2), it is generally expected that the residual strength will decrease for samples heated above $500-700{ }^{\circ} \mathrm{C}$ and $900{ }^{\circ} \mathrm{C}$. Based on the conducted experiments, it can be expected that samples heated to $1200{ }^{\circ} \mathrm{C}$ will decrease in residual strength by approximately $40 \%$ in comparison with the initial value determined at room temperature.

In sandstones with high uniaxial compressive strength, we can expect that residual strengths for heated samples $(100$ $900^{\circ} \mathrm{C}$ ) will oscillate around the strength values obtained in the conditions of room temperature. For this group, increases in residual strength vary between 8 and $65 \%$, while decreases vary between $3 \%$ and over $40 \%$. An example of stress-strain path characteristic of such a sandstone is presented in Fig. 7. For high uniaxial compressive strength samples from the Łaziska Beds, within the entire range of temperatures tested, residual strength decreased (Table 2). In samples heated to $100-500{ }^{\circ} \mathrm{C}$, a decrease in residual strength of between approximately 15 and $45 \%$ can be expected. In samples heated to $700-1000{ }^{\circ} \mathrm{C}$, the residual strength decreases to approximately $10 \%$ of the initial value of residual strength.

\section{Thermal influence of residual strain}

A similar analysis was conducted for results of residual strain. Indices of the thermal influence on residual strain (evaluated using Eq. (1)) were analyzed in the context of grain size and room temperature uniaxial compressive strength. Results are summarized in Table 3 and graphically presented in Fig. 8. The presentation of results is analogical to that of thermal effect on residual strength.

Residual strain increased for all samples heated to $700{ }^{\circ} \mathrm{C}$ and higher. The samples heated to greater temperatures

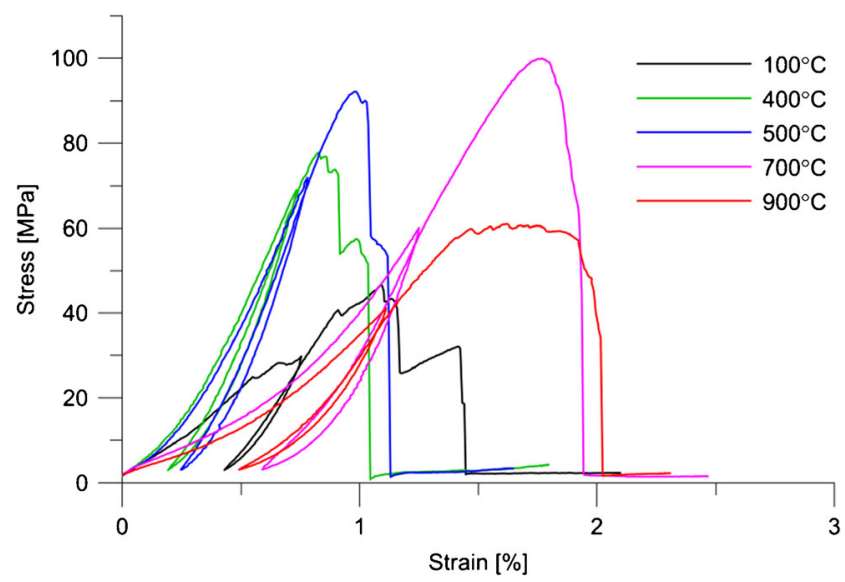

Fig. 7 Stress-strain paths for sandstone of high uniaxial compressive strength 
Table 3 Indices of thermal influence on residual strain of Carboniferous sandstones, Eq. (1)

\begin{tabular}{|c|c|c|c|c|c|c|c|c|c|c|c|c|c|}
\hline \multirow[t]{2}{*}{ No. } & \multirow[t]{2}{*}{ Sandstone grain size } & \multirow[t]{2}{*}{ Strength assessment } & \multicolumn{11}{|c|}{ Index of thermal influence on residual strain, Eq. (1) } \\
\hline & & & 100 & 200 & 300 & 400 & 500 & 600 & 700 & 800 & 900 & 1000 & 1200 \\
\hline 1 & Coarse-grained & V. low & 1.41 & 1.02 & 1.05 & 1.22 & 0.88 & 0.95 & 1.48 & 1.22 & 1.06 & 1.03 & - \\
\hline 2 & Coarse-grained & Low and medium & 0.77 & 0.79 & 0.74 & 0.98 & 0.90 & 1.12 & 1.21 & 1.33 & 1.26 & 1.14 & - \\
\hline 3 & Medium-grained & V. low and low & 1.11 & 0.88 & 1.26 & 1.38 & 1.87 & 1.80 & 2.32 & 1.64 & 1.95 & 2.00 & - \\
\hline 4 & Medium-grained & Medium & 0.85 & 0.88 & 0.84 & 0.73 & 0.97 & 1.38 & 1.49 & 1.34 & 1.40 & 1.16 & 1.66 \\
\hline 6 & Medium-grained & High & 1.37 & 1.30 & 1.28 & 1.51 & 1.16 & 1.74 & 2.34 & 2.36 & 2.42 & 1.81 & 2.03 \\
\hline 8 & Fine-grained & Medium (1) & 0.68 & 0.72 & 0.97 & 1.03 & 1.19 & 1.32 & 1.52 & 1.50 & 1.52 & 1.50 & 2.46 \\
\hline 9 & Fine-grained & Medium (2) & 0.81 & 0.87 & 0.64 & 0.91 & 0.87 & 1.08 & 1.60 & 1.48 & 1.48 & 1.41 & 1.56 \\
\hline 10 & Fine-grained & High & 1.30 & 1.27 & 1.67 & 1.40 & 1.27 & 1.88 & 1.97 & 1.73 & 1.97 & 1.73 & 1.44 \\
\hline
\end{tabular}

showed the greatest fluctuations in residual strain, although residual strain may have decreased, not changed, or increased.

USCB sandstones heated to $100{ }^{\circ} \mathrm{C}$ can either increase or decrease the residual strain in comparison to room temperature tests. In coarse-grained sandstones of low uniaxial compressive strength $(20.0-40.0 \mathrm{MPa})$, the residual strain decreased approximately $20 \%$; in medium-grained sandstones of medium uniaxial compressive strength (40.1-60.0 MPa), the residual strain decreased by $15 \%$, and in fine-grained sandstones of medium uniaxial compressive strength (40.1-
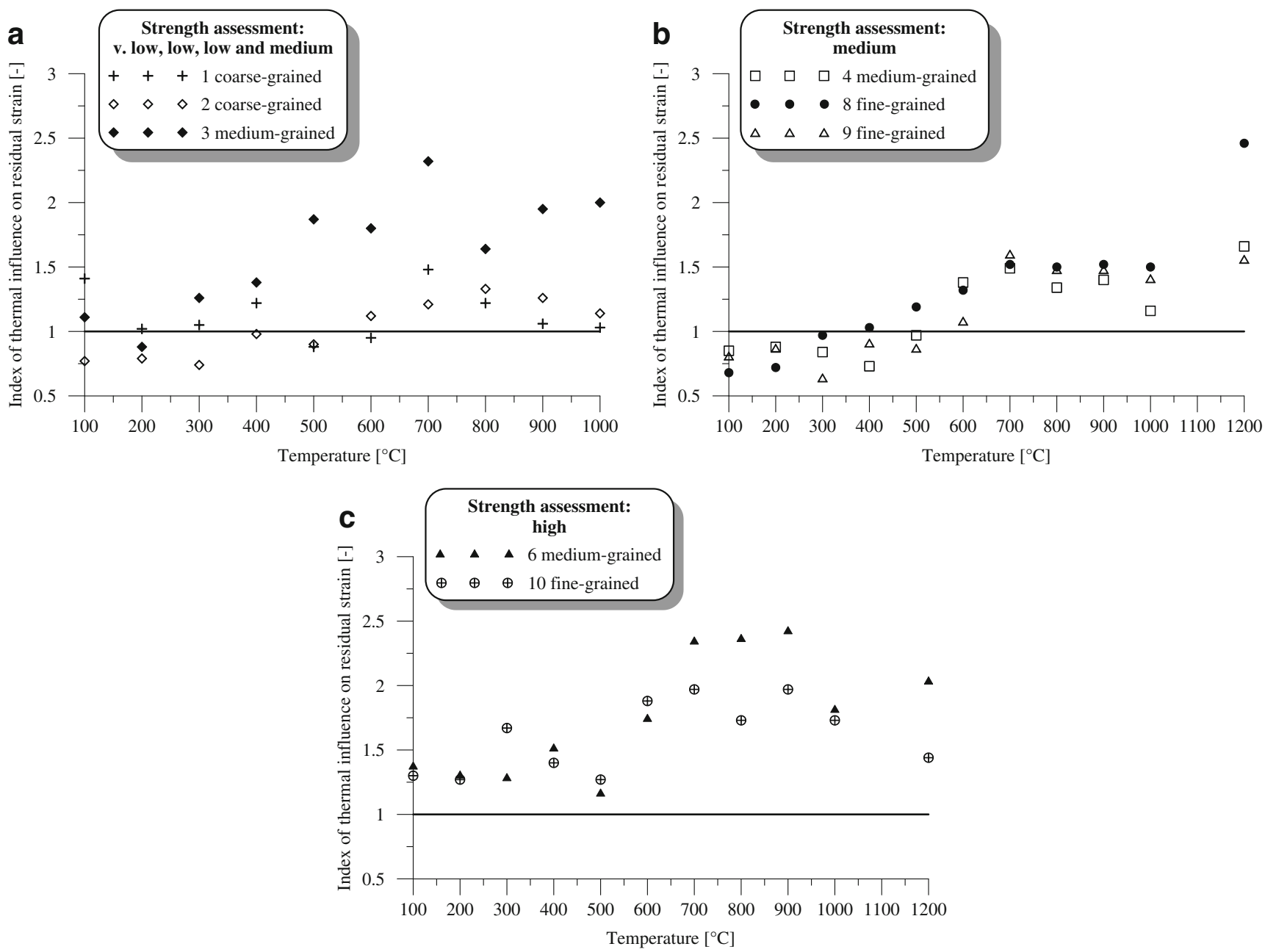

Fig. 8 Indices of thermal influence on residual strain versus temperature categorized by strength assessment. a V. low, low and medium, v. low and low. b Medium. c High 
60.0 $\mathrm{MPa}$ ), the residual strain decreased between approximately $20 \%$ and over $30 \%$. Indices of the thermal influence on residual strain at temperatures of up to 500 to $600{ }^{\circ} \mathrm{C}$ can be $0.64-1.88$.

Maximum increases in residual strain were observed at the temperature of $700-900{ }^{\circ} \mathrm{C}$, as follows:

for coarse-grained sandstone- $48 \%$,

for medium-grained sandstones- $142 \%$,

for fine-grained sandstones - $97 \%$,

for sandstones of very low, low, and medium uniaxial compressive strength- $132 \%$,

for sandstones of medium uniaxial compressive strength- $60 \%$,

for sandstones of high uniaxial compressive strength$142 \%$.

Sandstone samples heated to temperatures of 1000 to $1200{ }^{\circ} \mathrm{C}$ have thermal influence indices of residual strain between 1.03 and 2.46 .

The tests also showed differences between the residual strain changes in the three grain size classes; the residual strain may either increase or decrease.

The USCB sandstones of medium uniaxial compressive strength may decrease in residual strain if heated to $400{ }^{\circ} \mathrm{C}$, although at higher temperatures, the residual strain increases significantly. Residual strain may increase in heated sandstones of high uniaxial compressive strength, very low uniaxial compressive strength $(<20.0 \mathrm{MPa})$, and low uniaxial compressive strength $(20.0-40.0 \mathrm{MPa})$, with the exception of $100{ }^{\circ} \mathrm{C}$.

\section{Conclusions}

These laboratory tests aimed to determine the influence of temperature on the value of residual strength and residual strain of Carboniferous sandstones in the USCB, employing temperatures from room temperature to $1000-1200{ }^{\circ} \mathrm{C}$. Post-critical properties were obtained based on the stressstrain relationship measured during the loading of samples in a servo-controlled testing machine. The sandstone samples were retrieved from various lithostratigraphic members and structural units. The rocks differed in both age and in situ depth. Twenty-four series of sandstone samples were tested.

For sandstones of various uniaxial compressive strengths, as determined from room temperature air-dry tests, the residual strength increases with temperature to a critical temperature unique to the rock type. After exceeding the critical temperature, the residual strength decreases in comparison with its initial value. For the youngest beds of sandstone, which have medium and high uniaxial compressive strengths at room temperature, residual strength reductions can be expected at higher temperatures.

Sandstones of high uniaxial compressive strength (> 60.0 MPa) increase in residual strain for all heated samples. For sandstones of low (20.0-40.0 MPa) and medium (40.1$60.0 \mathrm{MPa}$ ) uniaxial compressive strength, an increase in residual strain can be expected after exceeding critical temperatures between 200 and $400{ }^{\circ} \mathrm{C}$.

The initial uniaxial compressive strength has a greater influence on the residual strain for heated samples than does grain size. Residual strain generally increases with temperature as a result of a decrease in elasticity, among other properties.

Recognition of the causes of the described behavior of tested parameters as a result of temperature treatment (from 100 to $1000-1200{ }^{\circ} \mathrm{C}$ ) requires further research. Authors are aware of the need to carry out research on mineralogical composition, geochemical studies, and even microstructural analysis. The latter if performed, e.g., in terms of nanoindentation or X-ray microcomputed tomography will provide important information on the changes of microstructural parameters due to temperature treatment (Cała et al. 2017). Such analyses are out of the scope of this paper. However, they are the subject of current research and the results will be published in future work.

The conducted research in terms of evaluation of postcritical parameters subjected to high temperatures as well as the method of analyzing the results are novel and are of primary importance from the engineering applications point of view. Knowledge and the ability to predict changes in post-critical parameters of rocks after high-temperature treatment allow to formulate an appropriate constitutive equation for the behavior of rock mass subjected to loads and affected by the temperature field. It is due to the fact that the loss of stability of the rock mass occurs in the postcritical regime, so after exceeding the maximum rock strength. Investigation of post-critical properties of rocks at the temperature significantly higher than examined so far allows formulating, in the future research works, elastic-plastic models with softening being a function of temperature.

Funding This article discusses research conducted under Research Project No. 11103066-142, funded by the Ministry of Science and Higher Education (Poland) and titled "Influence of temperature on the change of rock properties of Upper Silesian Sandstone Series in Upper Silesian Coal Basin.”

Open Access This article is distributed under the terms of the Creative Commons Attribution 4.0 International License (http:// creativecommons.org/licenses/by/4.0/), which permits unrestricted use, distribution, and reproduction in any medium, provided you give appropriate credit to the original author(s) and the source, provide a link to the Creative Commons license, and indicate if changes were made. 


\section{References}

Bhutto AW, Bazmi AA, Zahedi G (2013) Underground coal gasification: from fundamentals to applications. Prog Energy Combust Sci 39(1): 189-214. https://doi.org/10.1016/j.pecs.2012.09.004

Brotóns V, Tomás R, Ivorra S, Alarcón JC (2013) Temperature influence on the physical and mechanical properties of a porous rock: San Julian's calcarenite. Eng Geol 167:117-127. https://doi.org/10. 1016/j.enggeo.2013.10.012

Bukowska M (2012) The tendency to rock bumps-geological and geomechanical testing methods. Central Mining Institute, Katowice

Bukowska M (2013) Post-peak failure modulus in problems of mining geo-mechanics. J Min Sci 49(5):731-740. https://doi.org/10.1134/ s1062739149050067

Bukowski P (2015) Evaluation of water hazard in hard coal mines in changing conditions of functioning of mining industry in Upper Silesian Coal Basin-USCB (Poland). Arch Min Sci 60(2):455475. https://doi.org/10.1515/amsc-2015-0030

Bukowski P, Augustyniak I (2013) Changes in the structure of water inflow into coal mines in Poland. International Multidisciplinary Scientific GeoConference: SGEM 2:25-32. https://doi.org/10. 5593/sgem2013/ba1.v2/s02.004

Bukowski P, Niedbalska K (2013) The analysis of selected properties of solid rock materials designed for shafts liquidation. International Multidisciplinary Scientific GeoConference: SGEM 2:467-473. https://doi.org/10.5593/sgem2013/ba1.v2/s02.061

Cała M, Cyran K, Kawa M, Kolano M, Łydżba D, Pachnicz M, Rajczakowska M, Różański A, Sobótka M, Stefaniuk D, Stopkowicz A, Wałach D (2017) Identification of microstructural properties of shale by combined use of X-ray micro-CT and nanoindentation tests. Procedia Eng 191:735-743. https://doi.org/10. 1016/j.proeng.2017.05.239

Chaki S, Takarli M, Agbodjan WP (2008) Influence of thermal damage on physical properties on a granite rock: porosity, permeability and ultrasonic wave evolutions. Constr Build Mater 22(7):1456-1461. https://doi.org/10.1016/j.conbuildmat.2007.04.002

Chen YL, Ni J, Shao W, Azzam R (2012) Experimental study on the influence of temperature on the mechanical properties of granite under uni-axial compression and fatigue loading. Int J Rock Mech Min Sci 56:62-66. https://doi.org/10.1016/j.ijrmms.2012.07.026

Chodynicka L, Gabzdyl W, Kapuściński T (1993) Mineralogy and petrography for miner. Śląskie Wydawnictwo Techniczne, Katowice

Cieślik J (2015) Stress drop as a result of splitting, brittle and transitional faulting of rock samples in uniaxial and triaxial compression tests. Stud Geotech Mech 37(1):17-23. https://doi.org/10.1515/sgem2015-0003

Den'gina NI, Kazak VN, Pristash VV (1994) Changes in rocks at high temperatures. J Min Sci 29(5):472-477. https://doi.org/10.1007/ bf00733026

Dimitriyev AP, Kuzyayev LS, Protasov YI, Yamsbcbikov VS (1969) Physical properties of rock at high temperatures. Nedra Press, Moscow

Drzewiecki J, Kabiesz J (2008) Assessment criteria for innovative technologies in mining industry. Miner Resour Manag 24(1):43-51

Ferro AM, Marrini P (2001) Experimental studies on the mechanical behaviour of two thermal cracked marbles. Rock Mech Rock Eng 34(1):57-66. https://doi.org/10.1007/s006030170026

Gautam PK, Verma AK, Jha MK, Sarkar K, Singh TN, Bajpai RK (2016) Study of strain rate and thermal damage of Dholpur sandstone at elevated temperature. Rock Mech Rock Eng 49(9):3805-3815. https://doi.org/10.1007/s00603-016-0965-5

Hajpál M, Török Á (2004) Mineralogical and colour changes of quartz sandstones by heat. Environ Geol 46:311-322. https://doi.org/10. 1007/s00254-004-1034-z

Hettema MHH, de Pater CJ, Wolf KHAA (1992) High temperature properties of roof rock of coal. In: Hudson JA (ed) ISRM Symposium:
EUROCK'92. British Geotechnical Society, London, pp 93-98. https://doi.org/10.1016/0148-9062(93)92804-y

Hettema MHH, Wolf KHAA, de Pater CJ (1993) Thermo-mechanical properties of roof rock of coal for underground gasification. In: Dijksman JF, Nieuwstadt FTM (eds) Topics in applied mechanics. Kluwer Academic Publishers, Dordrecht, pp 347-354. https://doi. org/10.1007/978-94-011-2090-6_38

Heuze FE (1983) High-temperature mechanical, physical and thermal properties of granitic rocks - a review. Int J Rock Mech Min Sci Geomech Abstr 20(1):3-10. https://doi.org/10.1016/01489062(83)91609-1

Kabiesz J, Turek M, Drzewiecki J, Makówka J (2008) General criteria of innovativeness for assessing innovativeness of hard coal mining technologies by means of the AHP method. Miner Resour Manag 24(1):103-123

Keshavarz M, Fl P, Loret B (2010) Damage and changes on mechanical properties of gabbro thermally loaded up to $1000^{\circ} \mathrm{C}$. Pure Appl Geophys 167:1511-1523. https://doi.org/10.1007/s00024-0100130-0

Lu Y, Wang L, Sun X, Wang J (2016) Experimental study of the influence of water and temperature on the mechanical behaviour of mudstone and sandstone. Bull Eng Geol Environ 74(128):1-16. https://doi. org/10.1007/s10064-016-0851-0

Małkowski P, Kamiński P, Skrzypkowski K (2012) Impact of heating carboniferous rocks on their mechanical parameters. AGH J Min Geoeng 36(1):231-242

Mao X, Zhang L, Li T, Liu H (2009) Properties of failure mode and thermal damage for limestone at high temperature. Min Sci Technol 19:290-294. https://doi.org/10.1016/s1674-5264(09) 60054-5

Ranjith PG, Viete DR, Chen BJ, Samintha M, Perera A (2012) Transformation plasticity and the effect of temperature on the mechanical behaviour of Hawkesbury sandstone at atmospheric pressure. Eng Geol 151:120-127. https://doi.org/10.1016/j.enggeo. 2012.09.007

Rao Q, Wang Z, Xie H, Hie Q (2007) Experimental study of mechanical properties of sandstone at high temperature. J Cent S Univ Technol 14(1):478-483. https://doi.org/10.1007/s11771-007-0311-x

Shi L, Jinyu X (2015) An experimental study on the physico-mechanical properties of two post-high-temperature rocks. Eng Geol 185:6370. https://doi.org/10.1016/j.enggeo.2014.11.013

Siegesmund S, Mosch S, Scheffzük C, Nikolayev DI (2008) The bowing potential of granitic rocks: rock fabrics, thermal properties and residual strain. Environ Geol 55:1437-1448. https://doi.org/10.1007/ s00254-007-1094-y

Somerton WH (1992) Thermal properties and temperature-related behavior of rock/fluid systems. Elsevier, Amsterdam. https://doi.org/10. 1016/s0376-7361(09)x7002-0

Su CD, Guo WB, Li XS (2008) Experimental research on mechanical properties of coarse sandstone after high temperatures. Chin J Rock Mech Eng 27(6):1162-1170

Sygała A, Bukowska M, Janoszek T (2013) High temperature versus geomechanical parameters of selected rocks - the present state of research. J Sustain Min 12(4):45-51. https://doi.org/10.7424/ jsm130407

Tian H, Kempka T, Xu NX, Ziegler M (2012) Physical properties of sandstone after high temperature treatment. Rock Mech Rock Eng 45:1113-1117. https://doi.org/10.1007/s00603-012-0228-z

Tian H, Ziegler M, Kempka T (2014) Physical and mechanical behaviour of claystone exposed to temperatures up to $1000^{\circ} \mathrm{C}$. Int J Rock Mech Min Sci 70:144-153. https://doi.org/10.1016/j.ijrmms.2014.04.014

Tian H, Kempka T, Yu S, Ziegler M (2016) Mechanical properties of sandstones exposed to high temperature. Rock Mech Rock Eng 49:321-327. https://doi.org/10.1007/s00603-015-0724-z 
Ulusay R, Hudson JA (2007) The complete ISRM suggested methods for rock characterization, testing and monitoring: 1974-2006. Commission on Testing Methods ISRM, Ankara

Wang P, Jin-yu X, Shi L (2015) Ultrasonic method to evaluate the residual properties of thermally damaged sandstone based on time-frequency analysis. Nondestruct Test Eva 30(1):74-88. https://doi.org/10. 1080/10589759.2014.1002838

Wu G, Wang Y, Swift G, Chen J (2013) Laboratory investigation of the effects of temperature on the mechanical properties of sandstone. Geotech Geol Eng 31(2):809-816. https://doi.org/10.1007/s10706013-9614-x

Yavuz H, Demirdag S, Caran S (2010) Thermal effect on the physical properties of carbonate. Int J Rock Mech Min Sci 47:94-103. https://doi.org/10.1016/j.ijrmms.2009.09.014

Younger PL (2011) Hydrogeological and geomechanical aspects of underground coal gasification and its direct coupling to carbon capture and storage. Mine Water Environ 30:127-140. https://doi.org/10. 1007/s10230-011-0145-5

Zhang ZX, Yu J, Kou SQ, Lindqvist PA (2001) Effects of high temperatures on dynamic rock fracture. Int J Rock Mech Min Sci 38(2):211225. https://doi.org/10.1016/s1365-1609(00)00071-x

Zhang L, Mao X, Lu A (2009) Experimental study on the mechanical properties of rock at high temperature. Sci China Ser E Technol Sci 52(3):641-646. https://doi.org/10.1007/s11431-009-0063-y
Zhang L, Mao X, Liu R, Guo X, Ma D (2013) The mechanical properties of mudstone at high temperature: an experimental study. Rock Mech Rock Eng 47:1479-1484. https://doi.org/10.1007/s00603-013$0435-2$

Zhi-jun W, Zhao Y, Zhang Y, Chong W (2009) Research status quo and prospection of mechanical characteristics of rock under high temperature and high pressure. Procedia Earth Planet Sci 1:565-570. https://doi.org/10.1016/j.proeps.2009.09.090

Zuo J, Xie H, Zhou H, Peng S (2010) SEM in situ investigation on thermal cracking behaviour of Pingdingshan sandstone at elevated temperatures. Geophys J Int 181:593-603. https://doi.org/10.1111/j. 1365-246x.2010.04532.x

Publisher's note Springer Nature remains neutral with regard to jurisdictional claims in published maps and institutional affiliations. 